Вісник ЛДУБЖД

Bulletin of Lviv State University of Life Safety
ISSN 2078-4643 (print), ISSN 2708-1389 (online)

https://journal.ldubgd.edu.ua/index.php/Visnuk

УДК 159.9.072.432

DOI: $10.32447 / 20784643.21 .2020 .06$

\author{
Ewa Zieliński', Piotr Dzięgielewski², Maciej Zieliński', \\ Bernard Motylewski ${ }^{3}$, Dariusz Skalski ${ }^{4}$ \\ ${ }^{1}$ Collegium Medicum in Bydgoszcz, Nicolaus Copernicus University, Toruń, Poland. \\ ${ }^{2} X$ Military Clinical Hospital with the Polyclinic in Bydgoszcz \\ ${ }^{3}$ Collegium Medicum in Bydgoszcz, Nicolaus Copernicus University in Torun \\ ${ }^{4}$ Academy of Physical Education and Sport for them. of Jędrzej Śniadecki in Gdańsk
}

\title{
THE PROBLEM OF DISABILITY IN THE ASSESSMENT OF PARAMEDICS
}

The disability problem is an important issue that paramedics also face. Their attitudes and knowledge about this phenomenon may largely depend on the contact they make with a disabled person, and this in turn will be reflected in the activities that will be performed by the rescuer. The very method of collecting medical history is important in further rescue proceedings. The paper presents a variety of aspects in the approach to disability expressed in tests carried out on paramedics.

The intention of the authors was to signal the problem of disability and attempt to make a preliminary assessment of the subjective attitudes of medical students towards people with disabilities. This study is a preliminary report, and the leitmotiv of this publication is the willingness to interest the subject of other researchers and to share already available results.

Statistical analysis shows that among the causes of disability, the most common are damage and diseases of the musculoskeletal system $-46.5 \%$ in second place are cardiovascular diseases $-45.5 \%$, and neurological diseases to which we want to devote broad attention are in third place in this statistical and constitute $23.9 \%$.

The study was conducted in May 2019 in a group of 60 students (30 women and 30 men) aged 20-22 attending medical universities in the Kuyavian-Pomeranian Voivodeship.

The research tool was the author's own survey containing closed questions. Participation in the study was voluntary and anonymous. The respondents were asked about demographic data: the perception of the disabled, knowledge of problems related to the disabled and ways of supporting the disabled. The results were developed using Microsoft Excel 2010 from the Windows 7 package, using the appropriately available spreadsheet functions.

The obtained results justify the careful conclusion that the problem of disability, seen through the eyes of medical university students, is not only noticed but assessed by them. Students very emphatically referred to the problem of disabled people taken up in the article.

Key words: disability, paramedic, problems of people with disabilities

\section{Ева Зеліньські, Пйотр Дзенгелевські, Мацей Зеліньські, Бернард Мотилевські, Даріуш Скальскі}

\section{ДОСЛІДЖЕННЯ СПРИЙНЯТТЯ ПРОБЛЕМИ НЕПОВНОСПРАВНОСТІ МЕДИЧНИМИ ПРАЦВНИКАМИ}

Досить часто медичним працівникам у своїй роботі доводиться стикатися із неповносправними людьми. Те, як медики сприймають і розуміють цю проблему, визначає їх спілкування із неповносправними пацієнтами, що, в свою чергу, впливає на рівень наданої допомоги, адже він залежить від якості збору інформації про хворобу. У роботі висвітлено низку особливостей сприйняття медичними працівниками проблеми неповносправності, визначених за результатами проведення опитувань.

Цією роботою автори ставлять за мету нагадати усім про проблему неповносправності та дослідити субєктивне ставлення студентів медичних спеціальностей до неповносправних людей. Лейтмотивом проведених досліджень є також бажання привернути увагу інших дослідників та спонукати їх поділитися результатами подібних досліджень у цій області.

Аналіз статистики показує, що причиною неповносправності у 46,5\% випадків є вади опорно-рухового апарату, у 45,5\% - серцево-судинні хвороби і у 23,9\% випадків - неврологічні проблеми (саме вони і потребують найбільшої уваги). 
Дослідження були проведені у травні 2019 року з групою із 60 студентів (30 чоловіків і 30 жінок) віком 20-22 роки, що навчаються у медичних закладах освіти Куявсько-Поморського воєводства.

Для дослідження було використано анкетування. Усі запитання були розроблені авторами і потребували відповіді «так» або «ні». Участь у анкетуванні була добровільною і анонімною. Респондентів запитували про ставлення до неповносправних осіб, розуміння їх проблем, вміння надання допомоги та підтримки. Обробку результатів проводили за допогою табличного редактора Microsoft Excel 2010 (Windows 7).

За результатами досліджень можна обережно зробити висновок, що студенти медичних спеціальностей не тільки розуміють проблеми неповносправних людей, а й переймаються ними і проявляють емпатію.

Ключові слова: неповносправність, парамедики, проблеми неповносправних людей

„The basic principle of human rights is that established norms apply to every person, without dividing. However, these rights are still being denied to people with disabilities".

Thomas Hammarberg

- Council of Europe Commissioner for Human Rights in the years $2006-2012$

(from the Commissioner's position of September 21,

\section{Introduction}

Let's begin the considerations by trying to define what health is and what we understand by disability.

Among the many attempts to define the concept of health, the definition in the text of the Constitution of the World Health Organization (WHO) is the most widely known. The WHO definition states that health is complete, physical, psychological and social well-being of people, not just the absence of illness or disability $[1,2]$.

According to the same World Health Organization, disabilities were defined in 1980 as a limitation or inability to perform activities in a way or to the extent considered normal to humans, resulting from damage and impairment of body functions. Based on this definition, WHO defines people with disabilities as those who cannot independently, partially or completely, provide themselves with the possibility of a normal individual and social life as a result of physical or mental impairment which occurred during illness or injury, or this type of disease is of an inborn nature.

Also the body of the European Parliament, dealing with disability issues in 1994 as part of the European Disability Forum of the European Parliament, defined a disabled person as "a unit with all his or her rights, being in a disadvantageous situation due to environmental, economic and social barriers which, due to her damage can not overcome in the same way as other people. These barriers are all too often reinforced by depreciating attitudes from society. "

Disability (depending on the adopted criteria and divisions) refers not only to the limitation or lack of opportunities in professional activity, but in a broader sense, to performing or limiting to various degrees the social roles that a healthy person can usually play in everyday life. Analyze literature, the subject finds many attempts at defining the concept of disability in a different way, for example in J. Masow and V.P. Reno [3] presented a dozen or so different definitions that were constructed, for example, for the use of social organizations, insurance companies or for epidemiological and statistical purposes.

When considering the issue of disability in medical terms, we usually focus on assessing health, body and mind fitness in terms of choosing treatment, prosthesis or other type of medical support. We also have in mind the correlations resulting from the removal of barriers in daily activities, and the possibilities of therapy and rehabilitation of such people. [4]

The authors are aware of the fact that this type of survey has already been conducted and that publications presenting their results are available.

Statistical analysis shows that among the causes of disability, the most common are damage and diseases of the musculoskeletal system $-46.5 \%$ in second place are cardiovascular diseases $-45.5 \%$, and neurological diseases to which we want to devote broad attention are in third place in this statistical and constitute $23.9 \%$ [4]. It should be emphasized here that despite the improvement of living and social conditions, better access to broadly understood medical care or the functioning of various types of state institutions, the number of people with disabilities is not reduced.

According to the authors, such a significant percentage of disability associated with the nervous system and mental illness encourages to deal with this group of diseases. The authors are inclined to say that any additional research and scientific reports, not only broaden knowledge and allow for a broader statistical analysis, but also contribute to the propagation of changes in attitudes in society towards disabled people.

The study was conducted in May 2019 in a group of 60 students (30 women and 30 men) aged 20-22 attending medical universities in the Kuyavian-Pomeranian Voivodeship.

The research tool was the author's own survey containing closed questions. Participation in the study was voluntary and anonymous. The survey was addressed to able-bodied persons and an attempt was made to answer the following issues. The respondents were asked about demographic data: the perception of the disabled, knowledge of problems related to the 
disabled and ways of supporting the disabled. The results were developed using Microsoft Excel 2010 from the Windows 7 package, using the appropriately available spreadsheet functions.

Table 1 below presents the surveyed students by age and sex.

Table 1 - Research students by age and sex.

\begin{tabular}{|c|c|c|c|c|c|c|}
\hline \multirow{2}{*}{ Age } & \multicolumn{4}{|c|}{ Respondents } & \multicolumn{2}{c|}{ Altogether } \\
\cline { 2 - 7 } & \multicolumn{2}{|c|}{ Women } & \multicolumn{2}{c|}{ Men } & \multicolumn{2}{c|}{} \\
\cline { 2 - 7 } & Number & $\%$ & Number & $\%$ & Number & $\%$ \\
\hline $\begin{array}{c}20 \\
\text { years }\end{array}$ & 7 & 23 & 6 & 20 & 13 & 22 \\
\hline $\begin{array}{c}21 \\
\text { years }\end{array}$ & 14 & 47 & 15 & 50 & 29 & 48 \\
\hline $\begin{array}{c}22 \\
\text { years }\end{array}$ & 9 & 30 & 9 & 30 & 18 & 30 \\
\hline Sum & $\mathbf{3 0}$ & $\mathbf{1 0 0}$ & $\mathbf{3 0}$ & $\mathbf{1 0 0}$ & $\mathbf{6 0}$ & $\mathbf{1 0 0}$ \\
\hline \hline
\end{tabular}

Source: own research

Of the 60 correctly completed questionnaires qualified for the analysis, $30(50 \%)$ were completed by women and $30(50 \%)$ by men. At age 20 , there were $7(23 \%)$ women and $6(20 \%)$ men. At age 21, there were $14(47 \%)$ women and $15(50 \%)$ men. Whereas at the age of 22 there were $9(30 \%)$ women and $9(30 \%)$ men. As you can see, the largest group of respondents were women and men aged 21 years. Table 2 below presents the surveyed students by place of residence.

Table 2 - Research students by place of residence

\begin{tabular}{||l|l|l|l|l|l||}
\hline \multicolumn{3}{||l|}{ Place of residence } & \multicolumn{2}{l|}{ In all } \\
\hline City & \multicolumn{2}{|l|}{ Village } & \multicolumn{2}{l|}{} \\
\hline Number & $\%$ & Number & $\%$ & Number & $\%$ \\
\hline $\mathbf{4 0}$ & $\mathbf{6 7}$ & $\mathbf{2 0}$ & $\mathbf{3 3}$ & $\mathbf{6 0}$ & $\mathbf{1 0 0}$ \\
\hline
\end{tabular}

Source: own research

Most respondents lived in the city - 40 people, which constituted $67 \%$ of the sample, and 20 people lived in the countryside, i.e. $33 \%$ of the respondents.

\section{dents}

The perception of disabled people by stu-

The survey of students aged 20-22 examined the perception of disability. The results of the surveys are collected in Tables 3 and 4 and show charts $1-2$ d.

Table 3 - Perception of people with disabilities, taking the environmental aspect as the criterion for division.

\begin{tabular}{|l|l|l|}
\hline \multirow{2}{*}{ Possible answers } & \multicolumn{2}{|l|}{ Respondents } \\
\cline { 2 - 3 } & Number & $\%$ \\
\hline $\begin{array}{l}\text { The student environment has an } \\
\text { impact on how I view disabled } \\
\text { people }\end{array}$ & 32 & 53 \\
\hline A disabled person is an equal & 12 & 20 \\
\hline
\end{tabular}

\begin{tabular}{|l|l|l||}
\hline member of society & & \\
\hline $\begin{array}{l}\text { I don't think about disabled } \\
\text { people at all }\end{array}$ & 16 & 27 \\
\hline Sum & $\mathbf{6 0}$ & $\mathbf{1 0 0}$ \\
\hline
\end{tabular}

Source: own research

From among 60 respondents, as many as 32 people $(53 \%)$ replied that the student community has an impact on how I perceive the disabled. 12 people (20\%) replied that a disabled person is an equal member of society. 16 respondents $(27 \%)$ said that I do not think about disabled people at all. It follows that the largest group of respondents - 32 people (53\%), inclined to say that the perception of people with disabilities is most affected by the student community. However, as many as 16 people $(27 \%)$ do not think about the disabled at all.

Figure 1 below graphically illustrates how people with disabilities are perceived.

Chart 1 - Student opinion on disability.

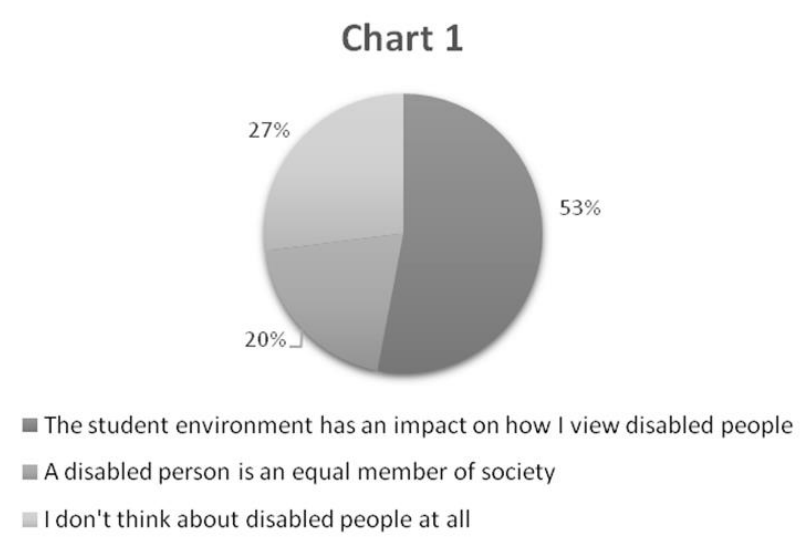

Source: own research

Table 4 below presents the perception of people with disabilities, taking as a criterion the division of the subjective opinion of the respondents regarding the disabled person

\begin{tabular}{|l|c|c|c|c|}
\hline Possible answers & YES & \multicolumn{3}{|l|}{ Noble 4 } \\
\cline { 2 - 5 } & Number & $\%$ & Number & $\%$ \\
\hline $\begin{array}{l}\text { The disabled person } \\
\text { should be able to } \\
\text { benefit from individu- } \\
\text { al learning and indi- } \\
\text { vidual studies }\end{array}$ & 21 & $35 \%$ & 39 & $65 \%$ \\
\hline $\begin{array}{l}\text { The disabled inspire } \\
\text { pity people }\end{array}$ & 34 & $57 \%$ & 26 & $43 \%$ \\
\hline $\begin{array}{l}\text { Disabled } \\
\text { arouse curiosity }\end{array}$ & $78 \%$ & 13 & $22 \%$ \\
\hline $\begin{array}{l}\text { I associate every } \\
\text { physical difference } \\
\text { with disability }\end{array}$ & 12 & $20 \%$ & 48 & $80 \%$ \\
\hline Source own ressary & & & & \\
\hline
\end{tabular}

Source: own research 
Affirmative to the question: Should a disabled person be able to benefit from an individual course of study and an individual course of study? 21 people responded (35\%). To the question: Does a disabled person arouse pity? affirmative answer was 34 people $(57 \%)$. To the question: Does a Disabled person arouse curiosity? yes (47\%). However, to the question: Is every physical difference associated with disability? 12 respondents answered in the affirmative (20\%). It follows that, according to the subjective opinion of the respondents, people with disabilities most often arouse curiosity and in 12 respondents, 12 people (20\%) are associated with physical disability.

Charts 2a, 2b, 2c, 2d below are graphically depicted the perception of people with disabilities, taking as a criterion the division of the subjective opinion of the respondents regarding the disabled person.

Chart 2 - The perception of the disabled

\section{Chart 2a}

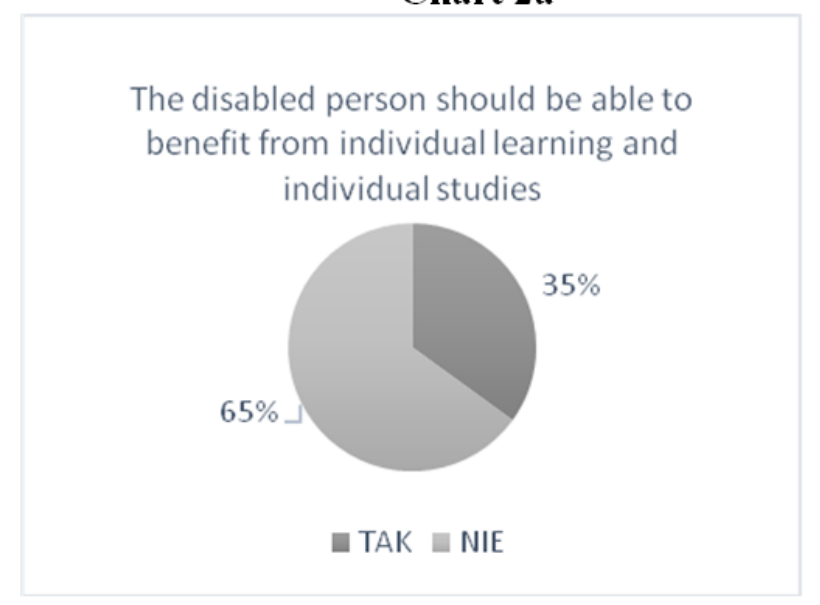

Chart 2b

The disabled person should be able to benefit from individual learning and individual studies

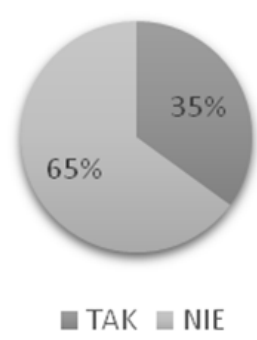

Chart 2c

Disabled people arouse curiosity

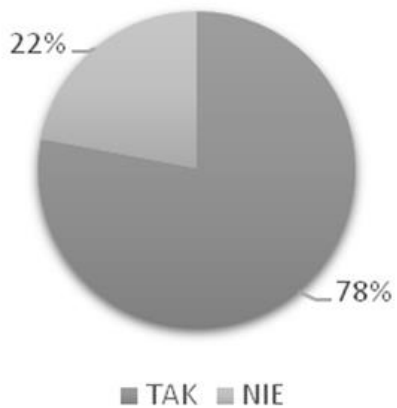

Chart 2d

I associate every physical difference with disability

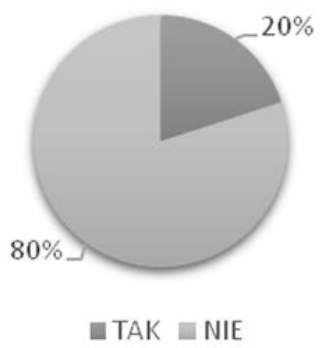

Source: own research

Knowledge of the problems of disabled people by students

A survey of 20-22-year-old students examined the knowledge of the problems of people with disabilities. The results of the surveys are collected in Tables 5 and 6 and show charts 3 and 4 .

Table 5 - Factors affecting unemployment of disabled people according to respondents.

\begin{tabular}{||l|l|l||}
\hline \multirow{2}{*}{ Influencing factors } & \multicolumn{2}{|c|}{ Research students } \\
\cline { 2 - 3 } & Number & \multicolumn{1}{|c|}{$\%$} \\
\hline $\begin{array}{l}\text { Ignorance of the needs of disabled } \\
\text { people by employers }\end{array}$ & 23 & $38 \%$ \\
\hline $\begin{array}{l}\text { Disability will affect the work } \\
\text { effects of other employees }\end{array}$ & 17 & $28 \%$ \\
\hline $\begin{array}{l}\text { Occurrence of many comorbidi- } \\
\text { ties and the employer's fear of the } \\
\text { possibility of adjusting the work- } \\
\text { place }\end{array}$ & 12 & $20 \%$ \\
\hline $\begin{array}{l}\text { Fear of long sick leave - frequent } \\
\text { absence }\end{array}$ & 8 & $13 \%$ \\
\hline Sum & 60 & $100 \%$ \\
\hline
\end{tabular}

Source: own research 
Among the respondents, as many as 23 students $(38 \%)$ declared ignorance of the needs of the disabled by employers. 17 respondents (28\%) responded positively to the fact that disability will affect the work results of other employees.

12 students $(20 \%)$ responded positively to the relationship between the occurrence of many comorbidities and the employer's fear of the possibility of adapting the workplace to the needs of the disabled. On the other hand, for fear of long sick leave, which may be associated with frequent absence from work, only 8 respondents affirmed (13\%). It can be concluded that among the factors affecting not employing the disabled according to the respondents, first of all the ignorance of the needs of the disabled by employers is ranked, and lastly, the employer's fear of long sick leave - frequent absenteeism.

Figure 3 below graphically illustrates the factors affecting the unemployment of disabled people, according to respondents.

Chart 3 - Factors affecting unemployment of disabled people according to respondents.

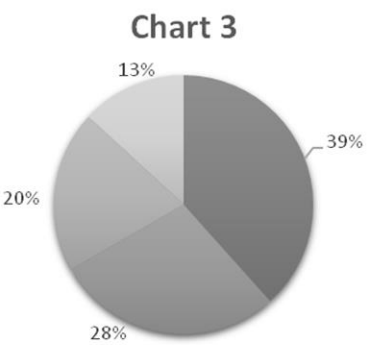

- Ignorance of the needs of disabled people by employers

Disability will affect the work effects of other employees

Occurrence of many comorbidities and the employer's fear of the possibility of adjusting the workplace

a Fear of long sick leave - frequent absence

Source: own research

Table 6 - Problems affecting everyday life of the disabled, according to respondents.

\begin{tabular}{||l|c|c||}
\hline \multirow{2}{*}{ IMPACT PROBLEM } & \multicolumn{2}{|c|}{ Pupils surveyed } \\
\cline { 2 - 3 } & Number & $\%$ \\
\hline Social intolerance & 26 & $47 \%$ \\
\hline Architectural barriers & 4 & $7 \%$ \\
\hline No social activity & 7 & $12 \%$ \\
\hline Lack of work & 18 & $30 \%$ \\
\hline Difficulties finding a partner & 5 & $8 \%$ \\
\hline Sum & 60 & $100 \%$ \\
\hline
\end{tabular}

Source: own research

Among problems affecting everyday life of the disabled, according to 26 respondents (47\%), social intolerance was ranked the highest. Also the fact of architectural barriers in the opinion of 4 respondents (7\%) was mentioned as significant. 7 people (12\%) pointed to the problem of physical inactivity among the disabled. In contrast, 18 students (30\%) mentioned lack of work as a problem affecting the daily life of people with disabilities. Only 5 respondents $(8 \%)$, as a factor having a significant impact on the everyday life of the disabled, mentioned difficulties in finding a partner. It follows that social intolerance was mentioned first, and difficulties in finding a partner were mentioned as an important reason, although it was classified last in the study.

Figure 4 below graphically illustrates the factors affecting the existence of disabled people according to respondents.

Chart 4 - Factors affecting the existence of the disabled, according to respondents.

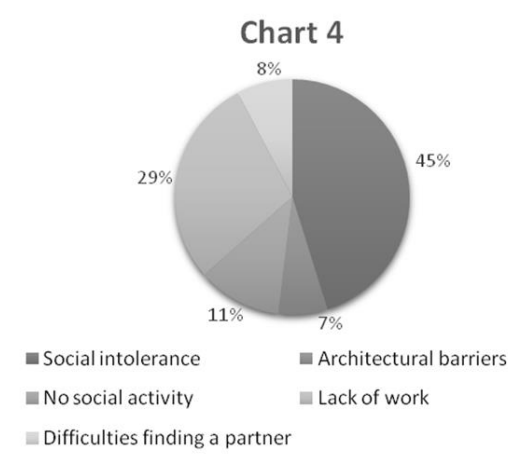

Source: own research

Knowledge of the possibilities of providing support to the disabled.

The survey conducted among students aged 2022 presents the image of students about the possibility of providing support to people with disabilities by individual institutions. The results of the survey are summarized in Table 7 and shown in Figure 5.

Table 7. below presents the image of students about the possibility of providing support for disabled people by individual institutions

Table 7 - Who should support people with disabilities according to respondents.

\begin{tabular}{||l|c|c||}
\hline \multirow{2}{*}{ Possible answers } & \multicolumn{2}{|c|}{ Pupils surveyed } \\
\cline { 2 - 3 } & Number & $\%$ \\
\hline $\begin{array}{l}\text { State institutions, including offices, } \\
\text { schools, universities, MOPS }\end{array}$ & 8 & $13 \%$ \\
\hline Associations, clubs & 9 & $15 \%$ \\
\hline Family & 14 & $23 \%$ \\
\hline Friends & 19 & $32 \%$ \\
\hline Health care facilities & 10 & $17 \%$ \\
\hline Sum & 60 & $100 \%$ \\
\hline
\end{tabular}

Source: own research 
In the opinion of 8 students (13\%), state institutions, including offices, schools, colleges and universities, were indicated as competent to provide support to people with disabilities. Also associations and clubs among the opinions of 9 respondents $(15 \%)$ were indicated as important in providing support to the disabled. 14 respondents $(23 \%)$ indicated that the family was important in providing support. 19 respondents (\%) also said that friends should provide support for the disabled. On the other hand, 10 people participating in the survey $(17 \%)$ expressed the opinion that health care facilities are intended to provide support to people with disabilities. From this it follows that the largest group of students participating in the study, i.e. 19 people (32\%) believe that friends should provide support to the disabled, and in the last place they classified state institutions including offices, schools, universities, MOPS. The group favoring this claim had 8 respondents $(13 \%)$.

Figure 5 below graphically illustrates the possibilities of providing support to disabled people according to respondents.

Chart 5 - Possibilities of providing support to the disabled according to the respondents.

\section{Chart 5}

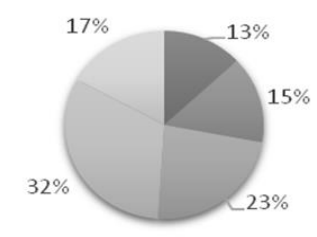

- State institutions, including offices, schools, universities, MOPS

Associations, clubs

- Family

ariends

- Health care facilities

Source: own research

The above fragments of a widely conducted research project may contribute to the continuation of research. The obtained results justify the careful conclusion that the problem of disability, seen through the eyes of medical university students, is not only noticed but assessed by them. Students very emphatically referred to the problem of disabled people taken up in the article. The authors in the study deliberately published the results obtained and processed fragmentarily, because without comparing them with other results of the research project, they could result in false inference. The intention of the authors was to signal the problem of disability and attempt to make a preliminary assessment of the subjective attitudes of medical students towards people with disabilities. This study is a preliminary report, and the leitmotiv of this publication is the willingness to interest the subject of other researchers and to share already available results. Due to the obvious fact that the issues discussed are widely described in the literature on the subject, there is still a noticeable deficit of studies and publications of research available to a wide range of interested parties. Hence, the decision of the authors of the project to write this preliminary report.

\section{References:}

1. Kulik T. B.: Koncepcje zdrowia w medycynie. W: Zdrowie publiczne. T. B. Kulik, M. Latalski (red.). Wydawnictwo Czelej, Lublin 2002: 18

2. Sokołowska M., Zdrowie a społeczeństwo. Zarys wybranych problemów. Warszawa 1972: 76-97.

3. Mashow J., Reno V. P. (red.): Balancing Security and opportunity: The challenge of disability income policy. Vashington DC National Academy of Social Insurancce, 1996: 795-800

4. Karta Praw Osób Niepełnosprawnych Uchwała Sejmu Rzeczpospolitej Polskiej z dnia 1 sierpnia 1997 r. (M.P. z dn. 13. 08. 1997 r. Nr 50, poz. 475)

\section{*Науково-методична стаття}

